\title{
Pendampingan Peningkatan Pengetahuan Konservasi Sumber Daya Ikan kepada Perempuan di Kecamatan Mangarabombang Kabupaten Takalar
}

\section{Assistance in Increasing Knowledge about Conservation of Fish Resources for Women in the Mangarabombang District, Takalar Regency}

\author{
Herman Pelani $^{1{ }^{*}}$, Yulia $^{2)}$, Baso Madiong ${ }^{2)}$ \\ ${ }^{1}$ Mahasiswa Pascasarjana Program Ilmu Hukum, Universitas Bosowa Makassar \\ ${ }^{2}$ Dosen Fakultas Hukum, Universitas Bosowa Makassar
}

Received 20 $0^{\text {th }}$ July 2019/Accepted $14^{\text {th }}$ August 2019

\begin{abstract}
ABSTRAK
Penelitian ini bertujuan untuk mengetahui pendampingan peningkatan pengetahuannkonservasi sumber daya ikankepada perempuan di Kecamatan Mamgarabombang Kabupaten Takalar. Penelitian ini dilaksanakan di lima (5) desa pesisir di Kecamatan Mangarabombang Kabupaten Takalar. Adapun populasi yang ditetapkan adalah keseluruhan perempuan yang bertempat tinggal di pesisir pantai. Peneliti menarik sampel untuk responden adalah 100 orang perempuan. dengan menggunakan model teknik random sederhana (Simple random sampling) Untuk penentuan sampel terhadap informan yang akan diwawancarai digunakan teknik pengambilan purposive sampling. Adapun teknik yang digunakan dalam pengumpulan data dari lokasi penelitian adalah wawancara dan Angket Analisis data menggunakan analisis kualitatif dan kuantitatif yang diprosentasekan. Hasil penelitian menunjukkan bahwa Kurangnya pengetahuan perempuan tentang konservasi sumber daya ikan di Kecamatan Mangarabombang mmpengaruhi kesadaran perempuan dalam konservasi sumber daya ikan. Kesadaran perempuan secara penuh akan hak dan kewajiban sebagai bagian yang mendapatkan mamfaat dari sumber daya ikan. Terbatasnya anggaran pemerintah menyebabkan program penyuluhan atau sosialisai tentang konservasi sumber daya ikan dikalangan masyarakat merupakan salah satu kendala. Disamping itu, tenaga penyuluh lapangan khusus yang menguasai konservasi sumber daya ikan sangat kurang. Sehingga diharapkan melalui sosialisasi khususnya terhadap perempuan pesisir dapat membawa mamfaat mengenai cara pengelolaan konservasi sumber daya ikan yang benar, karena dengan melakukan konservasi akan memberikan perlindungan, pemanfaatan dan pelesatarian sumber daya guna ketersediaan atau kekerlanjutan sumber daya ikan untuk generasi yang akan datang. Untuk mendukung kegiatan perempuan dalam konservasi sumber daya ikan akan dibentuk Kelompok Perempuan Pengelola Konservasi Sumber Daya Ikan (KP2SDI) guna peningkatan pengetahuan dan pemberdayaan perempuan mengenai konservasi sumber daya ikan.
\end{abstract}

Kata kunci: Pengetahuan, perempuan, konservasi sumber daya ikan

*Korespondensi:

email: yuliahasn@gmail.com 


\begin{abstract}
The aim of this research is to find out the assistance in increasing the knowledge of fish resources conservation to women in Mamgarabombang District Takalar Regency. This research was conducted in five (5) coastal villages in the District of Mangarabombang, Takalar Regency. The population determined is all women who live on the coast. Researchers drew samples for respondents from 100 women using simple random sampling models. For determining the sample of informants to be interviewed, a purposive sampling technique was used. The techniques used in collecting data from research locations are interviews and questionnaires. Data analysis uses qualitative and quantitative analyzes which are prospective. The results showed that the lack of women's knowledge about conservation of fish resources in the District of Mangarabombang influenced the awareness of women in the conservation of fish resources. Women's full awareness of the rights and obligations as part of getting benefits from fish resources. The limited government budget causes extension programs or socialization about conservation of fish resources among the community is one of the obstacles. In addition, there are very few special field counselors who master the conservation of fish resources. So that it is hoped that through socialization, especially coastal women can bring benefits on how to properly manage fish resource conservation, because carrying out conservation will provide protection, use and preservation of resources for the availability or sustainability of fish resources for future generations. To support women's activities in the conservation of fish resources, a Women's Management of Fish Resources Conservation Group will be formed to increase women's knowledge and empowerment regarding conservation of fish resources.
\end{abstract}

Keywords: Knowledge, women, conservation of fish resources

\title{
PENDAHULUAN
}

Sebagaimana yang diamanahkan pada pasal 67 UU No.45 Tahun 2009 tentang Perubahan terhadap UU No.31 Tahun 2004 tentang Perikanan, bahwa masyarakat ikut berperan dalam membantu melakukan pengawasan. Pengawasan yang melibatkan peran aktif masyarakat dalam mengawasi dan mengendalikan pengelolaan dan pemanfaatan sumber daya ikan secara bertanggungjawab agar dapat memperoleh manfaatnya secara berkelanjutan. Salah satunya adalah melakukan pegelolaan konservasi sumber daya ikan,merupakan kegiatan yang wajib dilakukan oleh pemerintah, pemerintah daerah maupun masyarakat, khususnya masyarakat petani ikan atau nelayan, sebab bagi masyarakat yang bermukim disekitar wilayah pesisir dan pulau-pulau kecil menggantungkan nasibnya pada penangkapan ikan, sehingga jika tidak dilakukan konservasi, maka akan berpengaruh pada pendapatan atau penghasilan dari masyarakat nelayan tersebut. Potensi sumber daya ikan kita tidak diragukan, tetapi jika tidak dilindungi, dimanfaatkan, dan dilestarikan akan berpengaruh pada kehidupan ekonomi negara. ${ }^{1}$ Berdasarkan Pasal 1 ayat (2) UU No.31 Tahun 2004 tentang Perikanan yang dimaksud sumber daya ikan adalah potensi semua jenis ikan. Sedangkan yang dimaksud

\footnotetext{
${ }^{1}$ Yulia. 2017. Implementasi Prinsip Perlindungan Konservasi Sumber Daya Ikan dalam Aktivitas Penangkapan Ikan di Indonesia (Desertasi). Universitas Hasanuddin.
} 
dengan ikan besrdasarkan Pasal 1 ayat (4) UU No.31 tahun 2004 tentang Perikanan adalah segala jenis organisme yang seluruh atau sebagian dari siklus hidupnya berada di dalam lingkungan perairan. Melalui peran perempuan diharapkan konservasi sumber daya ikan dapat dilakukan.

Peran perempuan dalam konservasi sumber daya ikan sangat dibutuhkan agar mampu menjaga keberlanjutan sumber daya ikan guna kepentingan generasi yang akan datang. Melalui peran perempuan, diharapkan lingkungan pesisir dan laut dapat terjaga, dengan memberikan pengetahuan tentang pentingnya konservasi sumber daya ikan. agar dapat diedukasikan kepada anak-anak, meskipun masih terbatas pada ruang domestik.

Pada masyarakat pesisir ada pembagian peran antara laki-laki dan perempuan. Laki-laki berperan pada urusan luar yaitu melaut dalam rangka mencari nafkah, sedangkan urusan domestik menjadi tanggungjawab perempuan. Potensi yang dimiliki perempuan diharapkan dapat memperbaiki lingkungan, baik secara individu maupun kelompok. Tentu saja pentingnya peran perempuan dalam konservasi sumber daya ikan perlu dibekali pengetahuan mengenai konservasi sumber daya ikan, karena dengan memberikan pengetahuan yang baik akan melahirkan sikap tindak yang baik pula dan menjadi contoh anak-anak mereka yang kelak akan mejadi pewaris perairan Indonesia.

Meskipun ada aturan untuk melakukan konservasi sumber daya ikan, tetap saja masih ada perilaku masyarakat pesisir yang dapat merusak ekosistem sumber daya ikan, sehingga mempengaruhi kehidupan sumber daya ikan tersebut seperti pembuangan limbah rumah tangga dan industri. Hal ini mempengaruhi kehidupan sumber daya ikan yang hidup dipesisir. Selain itu masih ada pelanggaran yang dilakukan oleh beberapa oknum nelayan dalam melakukan penangkapan ikan. menggunakan alat penangkapan ikan yang dilarang, seperti yang dilakukan oleh nelayan di Kecamatan Mangarabombang,masih ada oknum nelayan yang menggunakan alat penangkapan ikan yang dilarang. Tentu saja hal ini mempengaruhi ekosistem sumber daya ikan. Jika dulu nelayan melaut tidak perlu jauh dari pantai, sekarang mereka semakin ketengah laut untuk menangkap, karena dipesisir ikan semakin berkurang. Tentu saja ini mempengaruhi tingkat pendapatan para nelayan, karena harus mengeluarkan modal lebih banyak untuk menangkap ikan.

Oleh sebab itu, untuk melindungi, melestarikan, dan memanfaatan sumber daya ikan, diperlukan kerjasama antara pemerintah dan masyarakat. Pemerintah telah mengeluarkan aturan tentang konservasi sumber daya ikan, maka masyarakat harus berpartisipasi dalam melakukan konservasi tersebut. Salah satu bentuk partsipasi adalah melakukan pengawasan terhadap lingkungan laut agar sumber daya ikan tersedia dan terlindungi. Salah satu bentuk partisipasi masyarakat adalah dibentuknya Kelompok Masyarakat Pengawas (Pokmaswas) yang menngacu pada Keputusan Menteri Kelautan dan Perikanan Nomor 58/MEN/2001 tentang Tata Cara Pelaksanaan Sistem Pengawasan Masyarakat dalam Pengelolaan dan Pemanfaatan Sumber Daya Kelautan dan Perikanan (Dinas Kelautan Dan Perikanan 2017:15-17). Terbatasnya anggaran yang diberikan pemerintah merupakan salah satu kendala sehingga tidak semua daerah pesisir memiliki kelompok pengawas dan dibeberapa daerah Pokmaswas sudah tidak aktif. Sehingga masih ada kasus illegal fishing dengan menggunakan cara yang beragam 


\section{Pendampingan Peningkatan Pengetahuan Konservasi Sumber Daya Ikan kepada Perempuan di Kecamatan Mangarabombang Kabupaten Takalar}

mulai pengeboman ikan sampai penggunaan alat tangkap yang dilarang. ${ }^{2}$ Sehingga mengakibatkan kerusakan lingkungan Hal ini terjadi karena kurangnya pemahaman masyarakat tentang pentingnya konservasi sumber daya ikan, dan belum ada sinergi antara komponen yang terkait dalam pelaksanaan pengelolaan sumber daya ikan.

Oleh karena itu, peneliti menawarkan pelibatan perempuan dalam konservasi sumber daya ikan dengan memberikan pengetahuan tentang pentingnya konservasi sumber daya ikan, dengan alasan perempuan lebih peduli terhadap lingkungan dan perempuan dapat diajak berfikir kritis dibanding laki-laki. Selama ini ada pembagian peran nelayan, dimana kegiatan laki-laki menangkap ikan, sedangkan perempuannya mengolah dan menjual hasil tangkapan.Diharapkan dengan memberikan bekal pengetahuan kepada perempuan tentang konservasi sumber daya ikan maka kegiatan penangkapan ikan yangillegaldapat dicegah.

\section{METODE PENELITIAN}

Penelitian ini dilaksanakan di 5 (lima) desa di Kecamatan Mangara Bombang Kabupaten Takalar. .Adapun pertimbangan pemilihan lokasi karena di wilayah tersebut masih kurang perhatian nelayan terhadap pengelolaan konservasi SDI dan belum ada kelompok partisipasi perempuan yang dibentuk dalam rangka pengelolaan sumber daya ikan.

Adapun populasi yang ditetapkan adalah keseluruhan perempuan di Kecamatan Mangara Bombang kabupaten Takalar yang berdomisili di sekitar pantai. Peneliti menarik sampel untuk responden adalah 100 orang yang nanti akan dibagi dan disebar dibeberapa desa pantai.Setiap populasi mempunyai peluang yang sama untuk dipilih sebagai sampel, maka menggunakan model teknik random sederhana (Simple random sampling), yaitu warga populasi tidak dipilah-pilah atau distratakan terlebih dahulu. Dasar pertimbangannya adalah selain karena kapasitas dan kompetensinya yang cukup refresentatif untuk dipilih sebagai informan/narasumber, juga karena pertimbangan kemudahan menghadirkan mereka. Ini digunakan untuk menjawab rumusan masalah pertama dan kedua.

Untuk penentuan sampel terhadap informan yang akan diwawancarai digunakan teknik pengambilan sampel purposif (purposive sampling), yaitu teknik yang ditetapkan secara sengaja oleh peneliti yang berdasar atas kriteria atau pertimbangan tertentu.

Jenis data yang dihimpun dan dianalisis dalam penelitian ini adalah data primer dan data sekunder. Data primer adalah data empiris yang diperoleh secara langsung dari lokasi penelitian, baik dari hasil wawancara dan kuesioner. Sedangkan data sekunder adalah data yang bersumber dari proses studi kepustakaan, telaah dokumen khususnya laporan hasil penelitian dari berbagai pihak, jurnal, makalah, peraturan perundangundangan, dan sumber lain yang relevan dengan topik penelitian.

Adapun teknik yang digunakan dalam pengumpulan data dari lokasi penelitian adalah:

\footnotetext{
${ }^{2}$ Koran Tempo, 02 oktober 2015.
} 
1. Wawancara yaitu serangkaian pertanyaan secara lisan tidak tertulis yang telah disusun sebelumnya untuk diajukan kepada informan terpilih; di antaranya

a. Dinas Kelautan Perikanan Kabupaten Takalar

b. Tokoh masyarakat yang ada di Kecamatan Mangara Bombang

Pihak yang diwawancara akan berkembang sesuai dengan kebutuhan atau kepentingan penelitian.

2. Angket (Kuesioner) yaitu berupa daftar pertanyaan dalam bentuk pilihan ganda yang telah disiapkan untuk selanjutnya diedarkan kepada responden perempuan sejumlah 100 orang.

Dalam penelitian ini peneliti menggunakan analisis kuantitatif yang kemudian akan dikualitatifkan dengan rumus :

$\mathrm{f}$

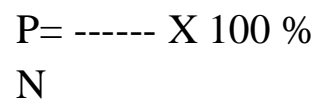

Jawaban responden selanjutnya diklasifikasikan dengan jalan memberi tanda dalam bentuk angka, menghitung frekuensi untuk dimasukkan dalam tabel dan di kualitatifkan.

\section{HASIL PENELITIAN DAN PEMBAHASAN}

\section{Kondisi Geogafi}

Jarak Makassar kepusat kota Kabupaten Takalar kurang lebih 40 km, dan jarak kota ke Kecamatan Mangarabombang kurang lebih $10 \mathrm{~km}$.. Keadaan georafi wilayah Kabupaten Takalar terdiri dari pantai, daratan dan perbukitan. Sebagian dari wilayah Kabupaten Takalar merupakan daerah pesisir pantai, yaitu sepanjang $74 \mathrm{Km}$ meliputi Kecamatan Mangarabombang, Kecamatan Mappakasunggu, Kecamatan Sandrobone, Kecamatan Gelesong Selatan, Kecamatan Galesong Kota dan Galesong Utara. Mangarabombang adalah salah satu kecamatan di Kabupaten Takalar yang terletak disebelah selatan dengan jarak kurang lebih 7 kilometer dari ibukota Kabupaten Takalar, dengan luas wilayah Kecamatan Managarabombang sekitar 100,50 km2 atau sebesar 17,74 persen total dari Kabupaten Takalar yang memiliki 11 desa dan 1 kelurahan dan juga merupakan Ibukota kecamatan yaitu Kelurahan Mangadu.. Adapun 11 (sebelas) desa di Kecamtan Mangarabombang sebagai berikut: Punaga, Laikang, Cikowang, Pattoppakang, Bontoparang, Panyangkalang, Bontomanai, Lakatong, Topejawa, Banggae, dan Lengkese. Dari 11 (sebelas) desa, 5 (lima) desa merupakan desa pesisir adalah Punaga, laikang, Cikowang, Topejawa, dang Banggae.

Berdasarkan data (Badan Pusat Statistik (BPS) Kabupaten Takalar,2018:13), jumlah penduduk Kecamatan Mangarabombang sekitar 38,913 jiwa, terdiri dari 18.643 laki-laki dan 20.270 jiwa perempuan, Desa laikang adalah yang terbesar jumlah penduduknya sekitar 5.069 jiwa dan Desa yang paling kecil jumlah penduduknya adalah Desa Bontoparang sekitar 2.093 jiwa. Adapun tingkat pendidikan masyarakat di Kecamatan Mangarabombang dapat dilihat pada tabel di bawah ini.

Tabel 1.Tingkat pendidikan masyarakat di kecamatan Mangarabombang 


\begin{tabular}{cccc}
\hline \multirow{2}{*}{ Desa/Kelurahan } & \multicolumn{3}{c}{ Tingkat Pendidikan } \\
\cline { 2 - 4 } & SD & SMP & SMA \\
\hline Punaga & 63 & 17 & - \\
Laikang & 117 & 81 & - \\
Cikowang & 66 & 128 & 186 \\
Topejawa & 84 & - & - \\
Banggae & 71 & - & - \\
\hline Jumlah & 401 & 226 & 186 \\
\hline
\end{tabular}

Sumber: BPS Kabupaten Takalar 2018

Berdasarkan data tersebut di atas rata-rata tingkat pendidikan masyarakat di Kecamatan Mangarabombang adalah tamatan Sekolah Dasar. Pekerjaan yang paling banyak digeluti adalah nelayan dan petani. Hasil kebun para petani berupa jagung, semangka dan kacang-kacangan. Sedangkan di desa-desa yang berada dipinggir laut ditemukan budidaya rumput laut. Para nelayan tersebut disamping melakukan budidaya rumput laut juga menangkap ikan.

Wilayah pesisir di desa-desa Kecamatan Mangarabombang memiliki kekayaan dan sumber daya alam hayati laut yang bervariasai seperti rumput laut, mangrove, terumbu karang, ikan, dan lain-lain. Disepanjang pesisir Desa Topejawa dan Laikang nampak beberapa lokasi pantai dijadikan objek wisata salah satunya adalah Pusat Pendidikan Lingkungan Hidup (PPLH) Putondo yang terletak di Desa Laikang yang banyak didatangi oleh para wisatawan. Secara geografi dan potensi sumber daya alam yang dimiliki Kecamatan Mangarabombang jika dikelola dengan baik dapat meningkatkan ekonomi dan kesejahteraan masyarakat

\section{Pengetahuan Perempuan tentang Konservasi Sumber Daya Ikan di Kecamatan Mangarabombang Kabupaten Takalar}

Idealnya masyarakat yang berdiam dipesisir pantai senantiasa memperhatikan lingkungan sekitar agar tampak bersih, namun dibeberapa titik pantai di Kecamatan Mangarabombang ditemukan sampah-sampah RT dan yang lainnya berserakan disepanjang pantai. Kurangnya kepedulian masyarakat ini tentu saja dapat merusak ekosistem laut dan membuat tidak nyaman para peminat wisata yang melwati desa-desa di Kecamatan Mangarabombang. Berdasarkan wawancara dengan Syamsuddin (Staf Pengendalian dan Konservasi Sumber Daya Ikan pada Dinas Kelautan dan Perikanan Kabupaten Takalar, Tgl 22 Mei 2019) bahwa untuk menangkap ikan, nelayan sekarang membutuhkan banyak biaya, karena sumber daya ikan dipesisir sangat kurang, maka nelayan mencari ikan di tengah laut. Ini salah satu pertanda bahwa Sumber daya ikan tersebut kondisinya sangat memprihatinkan, hal ini ditandai dengan ${ }^{3}$, (1) waktu melaut menjadi lebih panjang dari biasanya, (2) lokasi penangkapan ikan menjadi lebih jauh dari biasanya, (3) hasil tangkapan semakin menurun, (4) ukuran ikan sasaran semakin kecil, dan (5) biaya penangkapan (oprasional) yang semakin meningkat. Untuk itu perlu

\footnotetext{
${ }^{3}$ Widodo, Y., \& Suadi. 2014. Pengelolaan Sumberdaya Perikanan Laut. Yogyakarta: Gadjah Mada University Press.
} 
dilakukan konservasi sumber daya ikan.Konservasi tidak dapat dipisahkan dengan pengelolaan sumber daya ikan dan lingkungan secara keseluruhan.

Selama ini masyarakat yang berdiam dipesisir paling banyak memberikan konstribusi kerusakan terhadap ekosistem. Pengertian masyarakat berdasarkan Pasal 1 butir 32 Undang-Undang No.27 Tahun 2007 tentang Pengelolaan Wilayah Pesisir dan Pulau-Pulau Kecil adalah masyarakat yang terdiri atas masyarakat hukum adat, masyarakat lokal, dan masyarakat tradisional yang bermukim di wilayah pesisir dan pulau-pulau kecil. Masyarakat tradisional yang dimaksud di atas adalah masyarakat perikanan tradisional yang masih diakui hak tradisionalnya dalam melakukan kegiatan penangkapan ikan atau kegiatan lainnya yang sah di daerah tertentu yang berada dalam perairan kepulauan sesuai dengan kaidah hukum laut internasional. Jika UndangUndang Pesisir dan Pulau-Pulau Kecil menggunakan istilah masyarakat tradisional untuk kegiatan masyarakat yang melakukan penangkapan ikan atau yang lainnya, maka Undang-Undang No.31 Tahun 2004 tentang Perikanan menggunakan istilah nelayan.Para nelayan ini dalam menangkap sumber daya ikan tunduk pada ketentuan Undang-Undang Perikanan, khususnya Pasal 13 yang menyatakaan bahwa dalam pengelolaan sumber daya ikan, dilakukan upaya konservasi ekosistem, konservasi jenis ikan, dan konservasi genetika ikan.Dan ketentuan lebih lanjut Pasal 13 tersebut diatur dalam Peraturan Pemerintah No.60 Tahun 2007 tentang Konservasi Sumber Daya Ikan.

Peran perempuan dalam konservasi sumber daya ikan sangat dibutuhkan agar mampu menjaga keberlanjutan sumber daya ikan guna kepentingan generasi yang akan datang. Melalui peran perempuan, diharapkan lingkungan pesisir dan laut dapat terjaga, dengan memberikan pengetahuan tentang pentingnya konservasi sumber daya ikan. agar dapat diedukasikan kepada anak-anak, meskipun masih terbatas pada ruang domestik.

Melalui perannya sebagai seorang ibu dapat memberikan pendidikan dan penyadaran tentang pentingnya konservasi sumber daya ikan ditanamkan pada anakanak sejak dini ${ }^{4}$ sebagai tindakan preventif,agar anak terbiasa menjaga lingkungan dengan baik, sehingga terbentuk generasi yang peduli pada lingkungan, karena perempuan yang menjadi ibu merupakan jendela pertama bagi seorang anak. Perempuaan .memainkan peranan penting dalam memperkenalkan anak kepada dunia. Perilaku dan pandangan diperoleh seorang anak berasal dari perempuan yang dipanggil ibu. Perempuan dapat jadi penuntun dan mitra laki-laki dalam mendukung dan menopang segala kesulitan dalam mengatasi masalah kehidupan. Bagi laki-laki Makassar atau suami menempatkan perempuan sebagai manajer yaitu segala sesuatu yang datang dan masuk ke dalam rumah harus sepengetahuan dan izin perempuan atau istri, Dengan demikian perempuan dan laki-laki memiliki kesejajaran peran dan fungsi, walaupun memiliki hak dan kewajiban yang sama, tetapi terdapat batasan kerja individual yang terbentuk secara fitrah. Budaya Makassar tidak membatasi perempuan untuk beraktivitas manakala urusan rumah tangganya diselesaikan atau didahulukan. Oleh karena itu, para perempuan di Kecamatan Mangarabombang dapat dilibatkan atau

\footnotetext{
${ }^{4}$ Kementrian Pemberdayaan Perempuan dan Perlindungan Anak. (23 Februari 2016). Kaum Perempuan Sebagai Agent Of Change Lingkungan Hidup. https://www.kemenpppa.go.id/. Diakses pada tanggal 8 Juni 2019.
} 


\section{Pendampingan Peningkatan Pengetahuan Konservasi Sumber Daya Ikan kepada Perempuan di Kecamatan Mangarabombang Kabupaten Takalar}

berpartisipasi dalam melakukan konservasi sumber daya ikan. Sebagaimana yang diatur dalam Undang-Undang Nomor 27 Tahun 2007 tentang Pengelolaan Wilayah Pesisir dan Pulau-Pulau Kecil, pada Pasal 60 ayat (1) tentang hak masyarakat dalam Pengelolaan Wilayah Pesisir dan Pulau-Pulau Kecil mengatur bahwa:

(a) Memperoleh akses terhadap perairan yang telah ditetapkan HP-3;

(b) Memperoleh kompensasi karena hilangnya akses terhadap sumber daya pesisir dan pulau-pulau kecil yang menjadi lapangan kerja untuk memenuhi kebutuhan akibat pemberian HP-3 sesuai dengan peraturan perundangundangan;

(c) Melakukan kegiatan pengelolaan sumber daya pesisir dan pulau-pulau kecil berdasarkan hukum adat yang berlaku dan tidak bertentangan dengan peraturan perundang-undangan;

(d) Memperoleh manfaat atas pelaksanaan pengelolaan wilayah pesisir dan pulau-pulau kecil;

(e) Memperoleh informasi berkenaan dengan pengelolaan wilayah pesisir dan pulau-pulau kecil;

(f) Mengajukan laporan dan pengaduan kepada pihak yang berwenang atas kerugian yang menimpa dirinya yang berkaitan dengan pelaksanaan pengelolaan wilayah pesisir dan pulau-pulau kecil;

(g) Menyatakan keberatan terhadap rencana pengelolaan yang sudah diumumkan dalam jangka waktu tertentu;

(h) Melaporkan kepada penegak hukum atas pencemaran dan/atau perusakan wilayah pesisir dan pulau-pulau kecil yang merugikan kehidupannya;

(i) Mengajukan gugatan kepada pengadilan terhadap berbagai masalah pesisir dan pulau-pulau kecil yang merugikan kehidupan;

(j) Memperoleh ganti kerugian.

Berdasarkan hasil wawancara dengan Miftahuddin (Kasubid.Pengawasan Sumber Daya Kelautan dan Perikanan pada Kantor Dinas Kelautan dan Perikanan Propinsi Sulawesi Selatan, tagl 20 Mei 2019) menyatakan bahwa salah satu partisipasi masyarakat dalam knservasi sumber daya ikan adalah melibatkan dalam pengawasan dan mengendalikan pengelolaan dan pemanfaatan sumber daya ikan dengan membentuk Sistem Pengawasan Berbasis Masyarakat (SISWASMAS). Adapun fungsinya: (1) Melindungi kepentingan ekonomi nelayan dan pembudidaya ikan dalam mengoptimalkan produktifitas usaha, produksi dan keuntungan ekonomi serta mempertahankan kelangsungan usaha, (2) Melakukan pengawasan terhadap kegiatan perikanan dan pemanfaatan lingkungan pada perairan tempat usaha dan (3) Kegiatan pengawasan merupakan wujud dari peran peserta masyarakat dalam membantu pengawasan daalam rangka sistem pengawasan berbasis masyarakat. Atas dasar SISWASMAS maka dibentuklah Kelompok Masyarakat Pengawas (PokMasWas) berdasarkan Keputusan Menteri Kelautan dan Perikanan No.58 Tahun 2001 tentang Tata Cara Pelaksanaan Sistem Pengawasan Berbasis Masyarakat. Di Sulawesi Selatan terdapat 170 Pokmaswas aktif yang tersebar di 21 Kabupaten dan Kota Propinsi Sulawesi Selatan. Pokmaswas ini melakukan pengawasan pada daerah mereka masing- 
masing. Berdasarkan Undang-Undang 23 tahun 2014 tentanng Pemerintahan Daerah menyerahkan kewenangan pengawasan Pokmaswas pada Dinas Kelautan dan Perikanan Propinsi yang semula merupakan kewenangan pemerintah darah. Kewenangan tersebut mengakibatkan pengawasan Pokmaswas menjadi tidak efektif, karena luasnya wilayah kelautan yang harus diawasi sementara tenaga pengawasnya terbatas. Idealnya kewenangan pengawasan Pokmaswas diserahkan pada Dinas Kelautann dan Perikanan Kabupaten/Kota. Kewenangan yang diberikan kepada Dinas Kelautan dan Perikanan Propinsi didasarkan pada Pasal 27 ayat (2) Undang-Undang 23 tahun 2014 menyatakan memberikan kewenangan kepadaDaerahprovinsiuntukmengelolasumberdaya alam di laut meliputi:

a. Eksplorasi, eksploitasi, konservasi, dan pengelolaan kekayaan laut di luar minyak dan gas bumi;

b. Pengaturan administratif;

c. Pengaturan tata ruang;

d. Ikut serta dalam memelihara keamanan di laut; dan

e. Ikut serta dalam mempertahankan kedaulatan negara.

Keberadaan Undang-Undang Pemerintah Daerah diadakan tanpa adanya konsultasi publik, sehingga pemerintah daerah provinsi tidak siap menerima kewenangan yang dibebankan kepadanya. Tentu saja ini dapat mempengaruhi penerapan prinsip-prinsip konservasi sumber daya ikan yang diatur pada Pasal 2 ayat (2) yaitu konservasi sumber daya ikan dilakukan berdasarkan prinsip:

a. Pendekatan kehati-hatian;

b. Pertimbangan bukti ilmiah;

c. Pertimbangan kearifan lokal;

d. Pengelolaan berbasis masyarakat;

e. Keterpaduan pengembangan wilayah pesisir;

f. Pencegahan tangkap lebih;

g. Pengembangan alat penangkapan ikan, cara penangkapan ikan, dan pembudidayaan ikan yang ramah lingkungan;

h. Pertimbangan kondisi sosial ekonomi masyarakat;

i. Pemanfaatan keanekaragaman hayati yang berkelanjutan;

j. Perlindungan struktur dan fungsi alami ekosistem perairan yang dinamis;

k. Perlindungan jenis dan kualitas genetik ikan; dan

1. Pengelolaan adaptif.

Di Kabupaten Takalar terdapat 18 Pokmaswas, 2 Pokmaswas berada di Kecamatan Mangarabombang yaitu Pokmaswas Garudayya dan Pokmaswas Intel Bahari. Hanya saja Pokmaswas di Kecamatan Mangarabombang tidak produktif.

Tidak aktifnya Pokmaswas ini menurut Muhammad Kasim (Ketua Pokmaswas Garudayya, Wawancara tanggal 20 Juni 2019) karena: Kurangnya respon pihak aparat jika dilaporkan adanya kecurigaan pelanggaran penangkapan ikan dengan menggunakan alat penangkapan ikan yang dilarang yang dapat menyebabkan terjadinya illegal fishing.

Faktor manusia juga berpengaruh pada pada kelangsungan hidup sumber daya ikan disatu sisi dapat menjaga lingkungan tetapi disisi lain sebagai perusak lingkungan. 


\section{Pendampingan Peningkatan Pengetahuan Konservasi Sumber Daya Ikan kepada Perempuan di Kecamatan Mangarabombang Kabupaten Takalar}

Karena keserakahannya berusaha mengambil keuntungan dengan merusak kelangsungan hidup sumber daya ikan. Berbagai cara dapat dilakukan manusian agar keinginannya tercapai. Menangkap ikan menggunakan cantrang, bom dan lain-lain adalah yang dilarang. Oleh karena itu diperlukan kesadararan manusia dalam menjaga lingkungan, agar dapat mengembalikan keseimbangan lingkunngan hidup.

Berdasarkan hal tersebut kerusakan Sumberdaya kelautan dan perikanan dapat disebabkan oleh dua faktor utama yaitu ${ }^{5}$ :

1. Faktor alam adalah faktor kerusakan yang disebabkan oleh alam antara lain: hempasan gelombang, tsunami, dan kenaikan suhu air laut.

2. Faktor aktivitas manusia adalah kerusakan akibat akktivitas manusia pada umumnya disebabkan oleh kepentingan ekonomi serta pengetahuan dan kesadaran masyarakat yang rendah.

Berdasarkan Data Dinas Kelautan dan Perikanan Propinsi Sulawesi Selatan di Kabupaten Takalar terdapat 46 Cantrang. Cantrang merupakan salah satu alat penangkapan ikan yang dilarang berdasarkan Peraturan Menteri Kelautan dan Perikanan No.2/PERMEN-KP/2015 tentang Larangan Penggunaan Alat Penangkapan Ikan Pukat Hela (Trawls) dan Pukat Tarik (Seine Nets) Di wilayah Pengelolaan Perikanan Negara Republik Indonesia. Tetapi adanya protes beberapa kelompok nelayan di Jawa sehingga peraturan tersebut tidak diberlakukan untuk daerah Jawa, sedangkan di luar Jawa tidak. Inilah salah satu penyebab mengapa Dinas Kelautan dan Perikanan Propinsi Sulawesi selatan tidak melakukan penegakan hukum kepada nelayan yang menggunakan alat tangkap yang dilarang. Menurut Miftahuddin (Kasubid.Pengawasan Sumber Daya Kelautan dan Perikanan pada Kantor Dinas Kelautan dan Perikanan Propinsi Sulawesi Selatan, tagl 20 Mei 2019) menyatakan: Jangan ada diskriminasi dalam penerapan hukum, jika ada pelarangan penggunaan alat penangkapan ikan yang dilarang, semua daerah harus diberlakukan sama, jangan ada perbedaan perlakuan. Hal ini dapat menyebabkan timbulnya konflik antara penegak hukum dan nelayan.

Disatu sisi pemerintah ingin menegakkan aturan tersebut, tetapi lain sisi masyarakat merasa adanya peraturan tersebut dapat mengurangi pendapatan, bahkan tidak sedikit nelayan yang harus menganggur. ${ }^{6}$ hampir $70 \%$ alat tangkap yang digunakan nelayan adalah pukat, Meskipun ada masa transisi penggunaan alat tangkap tersebut, tetapi masa transisi pemberlakuan aturan tersebut juga harus jelas, dan penggunaan alat tangkap yang dilarang hanya boleh digunakan 12 mil dari laut wilayah mereka.

Menyikapi masalah penangkapan ikan dengan menggunakan alat penangkapan ikan yang dilarang meruapakan salah satu bentuk pelanggaran konservasi sumber daya ikan berdasarkan Peraturan Pemerintah (PP) N0.60 Tahun 2007 tentang Konservasi Sumber daya Ikan. ${ }^{7}$ Konservasi dapat berfungsi sebagai penyangga dan filter terhadap

\footnotetext{
${ }^{5}$ Dinas Kelautan dan Perikanan Provinsi Sulawesi Selatan. 2014. Buku Saku POKMASWAS. Dinas Kelautan dan Perikanan Provinsi Sulawesi Selatan.

${ }^{6}$ www.iosrjourna 1s.org. Yulia,etc. Law Enforcement on Conservation of Fish Resourcesin Indonesia.IOSR Journal Of Humanities And Social Science (IOSR-JHSS), 22(1), 64-69.

${ }^{7}$ Hasan, Y.A. 2015. Implementation of International Instruments In Indonesian Legislation In The Field of Conservation of Fish Resources. Journal of Humanity, 3(1), 96-105.
} 
dampak yang ditimbulkan oleh masyarakat dan kegiatan pembangunan. Konservasi sumber daya ikan dalam UU Perikanan No.31 Tahun 2004 adalah upaya perlindungan,pelestarian, dan pemanfaatan sumber daya ikan,termasuk ekosistem, jenis, dan genetik untuk menjamin keberadaan, ketersediaan, dan kesinambungannya dengan tetap memelihara dan meningkatkan kualitas nilai keanekaragaman sumberdaya ikan. Implementasi dari UU Perikanan No.31 2004 diturunkan dalam bentuk (PP) No.60 Tahun 2007 tentang konservasi sumber daya ikan yang mengatur lebih rinci tentang upaya pengelolaan konservasi ekosistem atau habitat ikan termasuk di dalamnya melalui pengembangan kawasan konservasi perairan sebagai bagian dari konservasi ekosistem. Berdasarkan Pasal 2 ayat (2), Konservasi sumber daya ikan dilakukan berdasarkan prinsip:a) pendekatan kehati-hatian, b) pertimbangan bukti ilmiah, c) pertimbangan kearifan lokal, d) pengelolaan berbasis masyarakat, e) keterpaduan pengembangan wilayah pesisir, f) pencegahan tangkap lebih, g) pengembangan alat penankapan ikan dan cara penangkapan ikan yang ramah lingkungan, h) pertimbangan kondisi sosial ekonomi masyarakat, dan i) pemanfaatan keanekaragaman hayati yang berkelanjutan.

Banyaknya pelanggaran konservasi sumber daya ikan yang terjadi, mendorong untuk melibatkan perempuan dalam pengelolaan konservasi sumber daya ikan, karena melalui peran perempuan diharapkan dapat membawa pengaruh positip terhadap lingkungan masyarakat sekitarnya. Sebagaiman yang telah diuraikan di atas bahwa paling tidak perempuan dapat mengedukasi keluarganya untuk berperilaku sesuai dengan norma dalam menjaga lingkungan sekitarnya. Apalagi keseharian perempuan dalam melakukan aktivitas tidak bisa terlepas dari alam. Jika lingkungan sekitarnya buruk, pertanda bahwa perempuan kurang mendapat pengetahuan tentang pengelolaan konservasi sumber daya ikan. Berdasarkan hasil penelitian pada desa pesisir di Kecamatan Mangarabombang tentang pengetahuaan perempuan mengenai konservasi sumber daya ikan ditemukan sebagai berikut:

Tabel 2. Tingkat Pengetahuan perempuan tentang konservasi sumber daya ikan

\begin{tabular}{lcccc}
\hline No & Desa/Kelurahan & Tidak memahami & Memahami & Jumlah Responden \\
\hline 1 & Punaga & 20 & 0 & 20 \\
2 & Laikang & 20 & 0 & 20 \\
3 & Cikowang & 20 & 0 & 20 \\
9 & Topejawa & 20 & 0 & 20 \\
10 & Banggae & 20 & 0 & 20 \\
\hline Jumlah & $\mathbf{1 0 0}$ & $\mathbf{1 0 0 \%}$ & $\mathbf{1 0 0}$ \\
\hline Prosentase & &
\end{tabular}

Sumber: olah data Primer: 2019

Berdasarkan data kuisioner yang peneliti sebarkan pada perempuan yang bertempat tinggal di desa pesisir yaitu Punaga, laikanng, Cikowang, Topejawa dan Banggae pada umumnya mereka tidak memahami tentang konservasi sumber daya ikan. Hal ini mengindikasikan kurangnya sosialisasi tentang pentingnya partisipasi masyarakat dalam melakukan konservasi sumber daya ikan. Demikian juga selama menempuh pendidikan,perempuan di Kecamatan Mangarabombang yang pada umumnya tamat SD dan,SMP, mereka tidak diberikan materi tentang pentingnya 


\section{Pendampingan Peningkatan Pengetahuan Konservasi Sumber Daya Ikan kepada Perempuan di Kecamatan Mangarabombang Kabupaten Takalar}

perlindungan dan pelestarian sumber daya ikan. Menurut peneliti adanya pengetahuan, kesadaran dan perilaku manusia dalam berinteraksi dengan lingkungan tidak terlepas dari pengetahuan yang didapatkan pada masa sekolah. Hasil wawancara peneliti dengan Saharuddin (Staf Bidang Pengelola Usaha Perikanan, tanggal 22 Mei 1019) menyatakan pada saat diberikannya bantuan alat penangkapan ikan yang ramah lingkungan secara tidak langsung mensossialisaikan konservasi sumber daya ikan melalui penggunaan alat tangkap yang ramah lingkungan. Alat tangkap ramah lingkungan merupakan salah satu cara untuk melindungi sumber daya ikan. Bagi nelayan yang mendapat bantuan tentu saja akan berprilaku sesuai dengan aturan penangkapan ikan yang legal. Tapi bagi nelayan yang tidak mendapatkan bantuan dapat saja menggunakan alat tangkap yang tidak ramah lingkungan. Bantuan alat tangkap ikan pada umumnya diberikan pada lakilaki untuk digunakan melaut. Perempuan akan mendapatkan hasil tangkapan ikan dari laki-laki untuk dikelola. Pengelolaan sumber daya ikan lebih banyak dilakukan oleh perempuan tetapi pengetahuan perempuan tentang hasil tangkapan ikan yang legal dan tidak, masih terbatas. Sasaran sosialisasi pemerintah selama ini hanya pada laki-laki yang aktif melaut, padahal perempuanpun perlu dibekali pengetahuan agar mampu menyikapi dan memberikan pendapat dan masukan kepada keluarga dan masyarakat guna mencegah pelanggaran konservasi sumber daya ikan.

Secara garis besar untuk menjamin konservasi sumber daya ikan dapat tercapai dengan baik, pada Pasal 7 ayat (2) Undang-Undang Perikanan, menetapkan kewajiban yang harus dipatuhi dalam melakukan usaha atau kegiatan pengelolaan perikanan, yaitu:

a. Jenis, jumlah, dan ukuran alat penangkapan, termasuk ukuran mata jaring.

b. Jenis, jumlah, ukuran, dan penempatan alat bantu penangkapan ikan yang dimaksud adalah sarana, perlengkapan, atau benda lain yang dipergunakan untuk membantu dalam rangka efisiensi dan efektifitas penangkapan ikan.

c. Daerah, jalur, dan waktu atau musim penangkapan ikan,

d. Persyaratan atau standar prosedur operasional penangkapan ikan,

e. Sistem pemantuan kapal perikanan,

f. Jenis ikan baru yang akan dibudidayakan,

g. Jenis ikan dan wilayah penebaran kembali serta penangkapan berbasis budidaya,

h. Pembudidayaan ikan dan perlindungan,

i. Pencegahan, pencemaran, dan kerusakan sumber daya ikan serta lingkungannya,

j. Ukuran atau berat minimum jenis ikan yang boleh ditangkap,

k. Suaka perikanan,

1. Wabah dan wilayah wabah penyakit ikan,

m. Jenis ikan yang dilarang untuk diperdagangkan, dimasukkan, dan dikeluarkan dari wilayah Republik Indonesia (NOMOR 41/PERMEN$\mathrm{KP} / 2014$, tidak ada alasan mengapa di larang, dan perlu dipublikasikan) Sosialisasikan.

n. Jenis ikan yang dilindungi. (Nomor 35/Permen-KP/2013 tentang Tata Cara Penetapan Status Perlindungan Jenis Ikan). 
Berdasarkan hasil wawancara beberapa perempuan di beberapa Desa di Kecamatan Mangarabombang mengenai jenis, ukuran dan alat tangkap yang boleh digunakan, mereka tidak tahu. Ikan, kepiting, lobster, dan lain-lain yang diberikan para lali-laki kepada mereka untuk dikelola tidak diperhatikan ukuran dan jenis ikannya,apakah penangkapannya sesuai dengan aturan.Bagi perempuan hasil tangkapan laki-laki harus diterima karena itu nafkah, kewajiban laki-laki kepada keluarganya guna membiayai kehidupan keluarga. Adanya kebutuhan ekonomi tersebut dapat memicu kerusakan lingkungan yang parah dipesisir. Pada umumnya penduduk pesisir tergolong miskin. Ketidakpastian hidup menyebabkan pola pemanfaatan ikan tidak terkendali. Oleh karena itu harus diberikan pemahaman kepada masyarakat tentang penting konservasi sumber daya ikan, karena kerusakan lingkungan laut pasti akan berdampak pada masyarakat. Untuk mewujudkan lingkungan yang baik, hukum membebankan kewajiban kepada setiap orang untuk memelihara kelestarian fungsi lingkungan. Apakah secara contrario dibalik kewajiban setiap orang untuk memelihara kelestarian fungsi lingkungan terdapat hak lingkungan. Jika secara moral setiap orang dilarang merusak lingkungan, apakah dalam perspektif moral lingkungan mempunyai hak. Peter Mahmud Marzuki ${ }^{8}$ menyatakan bahwa moral merupakan dasar berpijak hukum dan hukum harus mencerminkan moral.

Jika benar lingkungan memiliki hak, lantas bagaimana lingkungan mempertahankan haknya, jika haknya tersebut dilanggar. Menurut Teori Kepentingan, hak lingkungan lahir karena adanya kepentingan manusia akan lingkungan yang baik dan sehat. Lingkungan yang baik dan sehat adalah syarat mutlak untuk mewujudkan kehidupan manusia yang baik dan sehat pula. Adanya kepentingan tersebut manusia menciptakan hak untuk lingkungan agar lingkungan tidak rusak. Perbuatan merusak adalah perbuatan melanggar hak lingkungan dan sekaligus merugikan manusia. Kepentingan manusia adalah inti dari hak lingkungan. Terjadinya kerusakan lingkungan pada intinya berimplikasi pada kerugian terhadap kepentingan manusia. Di sini manusia menciptakan suatu hak moral bagi lingkungan, yaitu hak lingkungan untuk tidak dirusak. Tindakan merusak lingkungan adalah tindakan tidak bermoral dan merugikan, baik bagi lingkungan maupun kepentingan manusia.Untuk menghindari terjadinya perbuatan yang merusak lingkungan, maka lingkungan diberikan hak tidak dirusak. Dibalik hak lingkungan untuk tidak dirusak terdapat kepentingan manusia akan lingkungan yang tidak dirusak. Konklusinya adalah bahwa kepentingan manusia akan lingkungan yang baik dan sehat adalah landasaan filosofis lahirnya hak lingkungan. ${ }^{9}$

Undang-Undang Dasar 1945 menjamin bahwa warga negara atau masyarakat dalam kedudukannya di pemerintahan maupun di dalam pembangunan memiliki hak untuk berperan secara aktif dalam berbagai bentuk hak dan kemampuannya dalam pemerintahan. Perempuan adalah masyarakat tidak dikecualikan ikut berperan dan berpartisipasi dalam konservasi sumber daya ikan berupa:

1. Memberikan edukasi pada anak-anak dan keluarga tentang pentingnya konservasi sumber daya ikan

\footnotetext{
${ }^{8}$ Efendi, A'an. 2014. Hukum Lingkungan. Bandung: PT Citra Aditya Bakti.

${ }^{9}$ Ibid
} 


\section{Pendampingan Peningkatan Pengetahuan Konservasi Sumber Daya Ikan kepada Perempuan di Kecamatan Mangarabombang Kabupaten Takalar}

2. Pengawasan terhadap pengelolaan sumber daya ikan

3. Informasi awal kepada pihak yang berkepentingan tentang adanya pelanggaran,

Hal ini juga sejalan dengan penjelasan Dwi dalam Billy KSarwono ${ }^{10}$ menyatakan ada empat alasan bahwa perempuan dapat mengubah lingkungan menjadi lebih baik yaitu:

1. Secara fisiologis perempuan terlibat dalam waktu yang lebih lama dengan spesies kehidupan dimana perempuanlah yang merawat masa depan manusia.

2. Posisi perempuan di wilayah domestik merupakan tempat bayi-bayi ditransformasikan menjadi makhluk kultural.

3. Psikologi perempuan sebagai ibu membuahkan cara berfikir yang lebih rasional, konkrit disbanding dengan laki-laki,

4. Kaum perempuan yang bertanggungjawab terhadap wilayah domestik punya banyak andil dalam mengurangi jumlah sampah dengan melakukan $4 \mathrm{R}$ (Reduce, reuse, recyle, dan restore).

Kurangnya pengetahuan perempuan tentang konservasi sumber daya ikan di Kecamatan Mangarabombang mmpengaruhi kesadaran perempuan dalam konservasi sumber daya ikan. Kesadaran perempuan secara penuh akan hak dan kewajiban sebagai bagian yang mendapatkan mamfaat dari sumber daya ikan. Berdasarkan wawancara dengan H. Syamsuddin (Staf Pengelolaan Konservasi Sumber Daya Dinas Kelautan dan Perikanan Kabupaten Kabupaten Takalar, wawancara 22 Mei 2019) menyatakan selain ketidaktahuan perempuan mengenai konservasi sumber daya ikan, kemiskinan masyarakat juga mempengaruhi pengelolaan konservasi sumber daya ikan. Kurangnya hasil tangkapan para nelayan di Kecamatan Mangarabombang menyebabkan sumber daya ikan yang dilarang untuk ditangkappun dijaring, dan hasilnya diserahkan kepada perempuan untuk dikelola. Terbatasnya anggaran pemerintah menyebabkan program penyuluhan atau sosialisai tentang konservasi sumber daya ikan dikalangan masyarakat merupakan salah satu kendala. Disamping itu, tenaga penyuluh lapangan khusus yang menguasai konservasi sumber daya ikan sangat kurang, karena melalui penyuluh segala informasi mengenai aturan dan kebijakan pemerintah mengenai konservasi sumber daya ikan dapat disosialisasikan kepada masyarakat.Pada prinsipnya tujuan hakiki yang terkandung di dalam Peraturan Pemerintah No 60 Tahun 2007 tentang Konservasi Sumber Daya Ikan tersebut adalah agar terdapat kegiatan yang mengarah pada perlindungan sumber daya ikan secara keseluruhan, selama ini pemamfaatan sumber daya ikan lebih dominan dilakukan dibandingkan dengan perlindungan dan pelestarian, sehingga berdampak pada ekosistem perairan. Diharapkan melalui sosialisasi khususnya terhadap perempuan pesisir dapat membawa mamfaat mengenai cara pengelolaan konservasi sumber daya ikan yang benar. Selain itu mengembalikan pikiran serta perilaku perempuan sesuai dengan hakikat konservasi sumber daya ikan yaitu memberikan perlindungan, pemanfaatan dan pelesatarian sumber daya guna ketersediaan atau kekerlanjutan sumber daya ikan untuk generasi yang akan datang.

\footnotetext{
${ }^{10}$ Sarwono, B.K. 2010. Pemaknaan Isu Pemanasan Global dan Lingkungan di Media oleh kaum Perempuan Urban. Jurnal Ilmu Komunikasi, 8(2).
} 
Berdasarkan hasil penelitian yang diperoleh bahwa perempuan pesisir di Kecamatan Mangarabombang tidak memahami mengenai konservasi sumber daya ikan. Hal ini disebabkan karena kurangnya penyuluhan atau sosialisasi yang menyadarkan perempuan pentingnya melakukan konservasi sumber daya ikan. Dalam rangka menyadarkan perempuan untuk melakukan konservasi sumber daya ikan, peneliti memberikan kuisioner untuk mengukur kepedulian perempuan dalam rangka meningkatkan pengetahuan perempuan guna berperan pada konservasi sumber daya ikan dan hasilnya sebagai berikut:

Tabel 3. Sikap perempuan untuk berpartisipasi dalam konservasi sumber daya ikan

\begin{tabular}{lcccccc}
\hline \multirow{1}{*}{ Lokasi } & \multicolumn{2}{c}{ Setuju } & \multicolumn{2}{c}{ Tidak setuju } & \multicolumn{2}{c}{ Jumlah } \\
\cline { 2 - 7 } & Jml org & \% & Jml org & \% & Jml org & \% \\
\hline Punaga & 20 & 20 & 0 & 0 & 20 & 100 \\
Laikang & 20 & 20 & 0 & 0 & 20 & 100 \\
Cikowang & 20 & 20 & 0 & 0 & 20 & 100 \\
Topejawa & 20 & 20 & 0 & 0 & 20 & 100 \\
Banggae & 20 & 20 & 0 & 0 & 20 & 100 \\
\hline
\end{tabular}

Total responden $\quad 100$

Sumber: Olah data primer, 2019.

Berdasarkan hasil kuisioner pada umumnya perempuann yang berada di desa pesisir di Kecamatan Mangarabombang setuju diberikan pengetahuan tentang konservasi sumber daya ikan. Setelah tugas pokok perempuan dalam rumah tangga selesai banyak waktu luang yang dimiliki para perempuan, menurut mereka dapat digunakan untuk belajar mengetahui pentingnya konservasi sumber daya ikan. Menurut peneliti perempuan penting dilibat dalam perlindungan konservasi sumber daya ikan, sebab semakin banyak yang melakukan pencegahan dan pengawasan terhadap konservasi sumber daya ikan semakin kecil pelanggaran terjadi.

Pencegahan dan pengawasan pada konservasi sumber daya ikan bukan saja menjadi tanggung jawab pemerintah, tetapi merupakan tanggung jawab bersama masyarakat, untuk itu diperlukan kerja sama semua pihak yang terkait. Berpedoman pada pasal-pasal yang mengatur kegiatan yang merupakan pelanggaran terhadap konservasi sumber daya ikan yang diatur dalam Undang-undang Perikanan, dapat menjadi kontrol masyarakat untuk menindak pelaku pelanggaran tersebut.

Masih ada nelayan menangkap ikan dengan menggunakan alat tangkap yang dilarang di Kecamatan Mangarabombang membutuhkan perhatian serius.Jangan sampai pembiaran yang dilakukan justru membawa pada kerusakan yang lebih para pada sumber daya ikan. Pemanfaatan sumber daya ikan menempati posisi yang dominan, karena masyarakat pesisir sangat bergantung pada sumber daya ikan sebagai sumber makanan dan juga sebagai sumber pendapatan. Oleh karena itu dibutuhkan perhatian serius jika pemanfaatan sumber daya ikan lebih dominan dilakukan, dibandingkan dengan perlindungan dan pelestarian. Jika pemanfaatannya yang lebih banyak tanpa dibarengi dengan perlindungan dan pemanfaatan maka konservasi sumber daya akan 


\section{Pendampingan Peningkatan Pengetahuan Konservasi Sumber Daya Ikan kepada Perempuan di Kecamatan Mangarabombang Kabupaten Takalar}

tidak akan terjadi. Idealnya harus ada keseimbangan dalam pengelolaan konservasi sumber daya ikan.

Konservasi sumber daya ikan tidak hanya membutuhkan partisipasi masyarakat, tetapi juga dibutuhkan peran serta pemerintah pusat dan daerah. Maka dalam rangka meningkatkan partisipasi masyarakat sejumlah informasi dan pengetahuan teknik konservasi sumber daya ikan perlu diberikan kepada tenaga penyuluh guna disampaikan pada masyarakat, terutama penggunaan alat tangkap yang ramah lingkungan, menangkap ikan tidak boleh melebihi kapasitasnnya (overfishing) dan menangkap ikan sesuai dengan wilayah penangkapan ikan. Masih banyak yang memandang partisipasi masyarakat semata-mata sebagai penyampaian informasi (public information), penyuluhan, bahkan sekedar alat public relation, agar program kerja dapat berjalan tanpa hambatan. Oleh karena itu partisipasi masyarakat tidak saja digunakan sebagai sarana untuk mencapai tujuan, tetapi juga digunakan sebagai tujuan. Dengan demikian, pada umumnya keterlibatan dan pengakomodasian kepentingan masyarakat dalam mencapai maksud konservasi sumber daya ikan yaitu upaya perlindungan, pelestarian dan pemanfaatan sumber daya ikan, termasuk ekosistem, jenis, dan genetik untuk menjamin keberadaan, ketersediaan, dan kesinambungan dengan tetap memelihara dan meningkatkan kualitas nilai dan keanekaragaman sumber daya ikan.

Bentuk partisipasi masyarakat pada konservasi sumber daya ikan yang telah diuraikan di atas dapat dibedakan atas dua berdasarkan inisiatip pembentukan yatu:

1. Partisipasi masyarakat yang dibentuk oleh pemerintah seperti perencanaan konservasi dan Pokmaswas.

2. Partisipasi masyarakat dengan kesadaran sendiri, seperti pemanfaatan sumber daya ikan dan masyarakat peduli lingkungan.

Partisipasi masyarakat yang dibentuk oleh pemerintah merupakan program pemerintah yang harus direalisasikan dan telah dianggarkan, sehingga pembentukan kelompok partisipasi masyarakat dapat difungsikan. Keterbatasan anggaran yang diberikan oleh pemerintah merupakan salah satu kendala sehingga tidak semua daerah memiliki bentukan kelompok partisipasi masyarakat ini. Sedangkan partisipasi masyarakat dengan kesadaran sendiri adalah partisipasi yang dibangun dari kehendak dan inisiatip perempuan dalam mengelolah lingkungan. Kesadaran inilah yang dikehendaki oleh pemerintah, sepanjang kegiatan yang dilakukan oleh masyarakat tidak merusak dan mengakibatkan kerugian terhadap konservasi sumber daya ikan. Oleh karena itu, keberhasilan pengelolaan konservasi sumber daya ikan, tidak saja ditentukan oleh aparatur yang cakap, tetapi harus didukung dengan partisipasi masyarakat.

Oleh karena itu, agar konservasi sumber daya ikan di Kecamatan Mangarabombang dapat dilakukan, perlu dilibatkan perempuan karena alasan yaitu:

1. Masih adanya aktivitas nelayan yang menggunakan alat tangkap ikan yang tidak ramah lingkungan di Kecamatan Mangarabombang, dan kurang dipedulikan oleh kelompok masyarakat tertentu.

2. Bahwa perempuan perlu dibekali pendidikan tentang pentingnya konservasi sumber daya ikan sebagai tindakan preventif yang dapat diedukasikan kepada 
anak-anaknya dan masyarakat agar cara pandang dan sikap sesuai dengan tujuan konservasi sumber daya ikan.

3. Bahwa perempuan memiliki hak di pemerintahan maupun di dalam pembangunan untuk ikut berperan dan berpartisipasi dalam konservasi sumber daya ikan.

Berdasarkan hal tersebut di atas peneliti menawarkan model pelibatan perempuan dalam konservasi sumber daya ikan dengan membentuk Kelompok Perempuan Pengelola Konservasi Sumber Daya Ikan (KP2SDI). Kelompok ini akan dibentuk oleh perempuan yang berada di Kecamatan Mangarabobang. Sebelum dibentuk kelompok, para perempuan akan dibekali pengetahuanmengenai langkah-langkah yang dapat dilakukan dalam mendukung konservasi sumber daya ikan. Adapun tugas kelompok:

1. Pemberdayaan perempuan untuk peningkatan pengetahuan mengenai konservasi sumber daya ikan sebagai upaya preventif.

2. Memberikan pengetahuan kepada keluarga dan masyarakat dan mengajak untuk menjaga lingkungan agar bersih dan sehat..

3. Memberikan konseling setiap kejadian pelanggaran yang dilakukan oleh keluarga dan masyarakat.

4. Membuat laporan kejadian pelanggaran konservasi sumber daya ikan yang disaksikan dan ditujukan kepada pengawas perikanan.

Ruang lingkup kerja KP2SDI hanya pada wilayah pesisir pantai sesuai dengan pembagian kerja nelayan yaitu perempuan yang mengurus wilayah domestik dan lakilaki yang melaut. Adapun peranan KP2SDI adalah memberikan edukasi kepada keluarga dan masyarakat dalam melakukan konservasi sumber daya ikan.

\section{PENUTUP}

Pendampingan peningkatan pengetahuan konservasi sumber daya ikan kepada perempuan di Kecamatan Mangarabombang perlu dilakukan, karena hasil penelitian menunjukkan bahwa kurangnya pengetahuan perempuan tentang konservasi sumber daya ikan Kurang ksesadaran perempuan secara penuh akan hak dan kewajiban sebagai bagian yang mendapatkan mamfaat dari sumber daya ikan. Terbatasnya anggaran pemerintah menyebabkan program penyuluhan atau sosialisai tentang konservasi sumber daya ikan dikalangan masyarakat tidak dilakukan. Selain itu, tenaga penyuluh lapangan khusus yang menguasai konservasi sumber daya ikan sangat kurang,Melalui sosialisasi diharapkan perempuan pesisir dapat mengetahui mamfaat pengelolaan konservasi sumber daya ikan yang benar, karena dengan melakukan konservasi akan memberikan perlindungan, pemanfaatan dan pelesatarian sumber daya guna ketersediaan atau kekerlanjutan sumber daya ikan untuk generasi yang akan datang. Untuk mendukung kegiatan perempuan dalam konservasi sumber daya ikan akan dibentuk Kelompok Perempuan Pengelola Konservasi Sumber Daya Ikan (KP2SDI) guna peningkatan pengetahuan dan pemberdayaan perempuan dalam konservasi sumber daya ikan. 


\section{Terimakasih kepada:}

Direktorat Riset dan Pengabdian Masyarakat dan Direktorat Jenderal Penguatan Riset dan Pengembangan pada Kementerian Riset, Teknologi, dan Pendidikan Tinggi yang telah membiayai Penelitian Tesis Magister ini untuk anggaran tahun 2019.

\section{DAFTAR PUSTAKA}

Dinas Kelautan dan Perikanan Provinsi Sulawesi Selatan. 2014. Buku Saku POKMASWAS. Dinas Kelautan dan Perikanan Provinsi Sulawesi Selatan.

Efendi, A’an. 2014. Hukum Lingkungan. Bandung: PT Citra Aditya Bakti.

Hasan, Y.A. 2015. Implementation of International Instruments In Indonesian Legislation In The Field of Conservation of Fish Resources. Journal of Humanity, 3(1), 96-105.

Kementrian Pemberdayaan Perempuan dan Perlindungan Anak. (23 Februari 2016). Kaum Perempuan Sebagai Agent Of Change Lingkungan Hidup. https://www.kemenpppa.go.id/. Diakses pada tanggal 8 Juni 2019.

Koran Tempo, 02 oktober 2015.

Sarwono, B.K. 2010. Pemaknaan Isu Pemanasan Global dan Lingkungan di Media oleh kaum Perempuan Urban. Jurnal Ilmu Komunikasi, 8(2).

Widodo, Y., \& Suadi. 2014. Pengelolaan Sumberdaya Perikanan Laut. Yogyakarta: Gadjah Mada University Press.

Yulia. 2017. Implementasi Prinsip Perlindungan Konservasi Sumber Daya Ikan dalam Aktivitas Penangkapan Ikan di Indonesia (Desertasi). Universitas Hasanuddin.

Yulia, Patittingi, F., Manuputty, A., \& Hendrapati, M. 2017. Law Enforcement on Conservation of Fish Resources in Indonesia. IOSR Journal Of Humanities and Social Science (IOSR-JHSS). 22(1), 64-69. 